\title{
Transcriptionai Activation and DNase I Hypersensitive Sites Are Associated with Selective Expression of the Gastrin-releasing Peptide Gene
}

\author{
Sanford Markowitz, * Geoffrey Krystal," Anne-Marie Lebacq-Verheyden, * James Way, \\ Edward A. Sauśville," and James Battey* \\ *National Cancer Institute-Navy Medical Oncology Branch and Naval Hospital, Bethesda, Maryland 20814; and Department \\ of Medicine, Uniformed Services University of the Health Sciences, Department of Defense, Bethesda, Maryland 20892
}

\begin{abstract}
The gastrin-releasing peptide (GRP) is a neuropeptide hormone and growth factor produced normally by neural and neuroendocrine cells, as well as by human small-cell lung cancer (SCEC) tumors and derived cell lines. This study compares the structure of the human prepro-GRP gene in four SCLC cell lines that express variable levels of steady-state GRP mRNA: The regulation of GRP gene expression appears to be at the level of primary transcription based on nuclear run on studies. In the two SCLC cell lines expressing GRP we find a single transcription start site for GRP mRNA, and near this site we find four DNase I hypersensitive sites. These hypersensitive sites are absent in the two cell lines that do not express GRP. The presence of DNase hypersensitive sites in the promoter region of the GRP gene is the structural feature that best correlates with transcriptional activation. These four DNase hypersensitive sites are candidates for cis acting regulatory regions, which may be important in determining the level of transcription of the human prepro GRP gene.
\end{abstract}

\section{Introduction}

The gastrin-releasing peptide (GRP) ${ }^{1}$ is the mammalian homologue of the amphibian peptide bombesin with the carboxyl terminal 10 amino acids of GRP and bombesin sharing identity in 9 of 10 positions (1). GRP is present in brain (2-4), in neurons of the gut (5), and in pulmonary endocrine cells of fetal bronchus (6). Human tumors that produce GRP include pulmonary carcinoids $(7,8)$, medullary carcinomas of the thy-

Portions of this work were presented at the Annual Meeting of the American Society of Clinical Oncology, Atlanta, GA, April 1987, and at the UCLA Symposium: Growth Regulation of Cancer, Park City, UT, January 1987, and were published in abstract form (1987. Proc. Am. Soc. Clin. Oncol. 6:A61, and 1987. J. Cell. Biochem. Suppl. 11A:A147).

Dr. Markowitz's present address is Department of Medicine and the Ireland Cancer Center, Case-Western Reserve University, Cleveland, Ohio 44106. Address reprint requests to Dr. Sanford Markowitz, R. Livingston Ireland Cancer, University Hospitals of Cleveland, 2074 Abington Road, Cleveland, OH 44106.

Received for publication 10 August 1987 and in revised form 14 April 1988.

1. Abbreviations used in this paper: AVP, arginine vasopressin; GRP, gastrin-releasing peptide; SCLC, small cell lung cancer.

J. Clin. Invest.

(c) The American Society for Clinical Investigation, Inc. 0021-9738/88/09/0808/08 $\$ 2.00$

Volume 82, September 1988, 808-815 roid $(9,10)$, and most small-cell lung cancers (11). Cell lines derived from biopsies of human small-cell lung cancer tissue (SCLC) frequently produce GRP, and GRP production persists in culture over periods greater than two years $(12,13)$. GRP is a mitogen for Swiss 3T3 cells (14), for normal bronchial epithelial cells (15) and for some SCEC cell lines (16-18). GRP may be an autocrine growth factor for some SCLC lines that produce GRP, exhibit a mitogenic response to GRP, and show growth inhibition in vivo and in vitro in the presence of monoclonal antibodies to GRP (17). The structures of GRP cDNA clones derived from both a pulmonary carcinoid (19) and a SCLC cell line (13) have been determined, and a threeexon GRP gene from a human placental library has been cloned and structurally analyzed (20). However, the molecular mechanisms governing the transcriptional activation of the GRP gene remain uncharacterized.

Control of gene expression is thought to reside in part in recognition of DNA sequences near the site of initiation of the mRNA transcript (21). Several genes are now described in which RNA transcription is initiated from more than one defined site in either the same or differing tissues (22-25). Changes in gene structure that have been associated with gene expression include gene rearrangement (24), gene amplification (26-29), and changes in chromatin structure $(30,31)$. These chromatin structural changes include decreases in DNA methylation and acquisition of sites of DNase I hypersensitivity (30-34). Commonly in the region of actively transcribed genes short regions of chromatin acquire 10- to 100-fold increased sensitivity to digestion by DNase I as compared with chromatin of inactive genes (30). Such DNase I hypersensitive sites can be detected before the expression of both developmentally regulated genes and hormonally regulated genes $(30$, 35-38), and commonly, though not invariably, cluster 5 to the coding portion of the gene. They include the binding sites of specific regulatory proteins (30) such as the Drosophila heat shock transcription factor and the eukaryotic nuclear regulatory protein Spl (21, 30, 39-42).

To elucidate some of the molecular mechanisms involved in activating GRP gene expression in SCLC, we have examined each of the above regulatory motifs in four human SCLC cell lines that express variable amounts of GRP. These studies establish that varying levels of steady-state GRP mRNA directly correlate with the level of primary transcription measured in nuclear run-on studies. We find that transcription of the GRP gene in SCLC proceeds from a unique start site and that the structural feature best correlating with GRP gene expression is the presence near the GRP promoter of four specific DNase I hypersensitive sites observed only in cell lines that express GRP. In a limited survey, we see no evidence for a regulatory role for methylation near the GRP promoter, for gene amplification or for gene rearrangement. 


\section{Methods}

Cell lines. SCLC cell lines NCI-H82, NCI-N417, NCI-H209, and NCI-H510 were maintained in RPMI supplemented with $10 \%$ fetal bovine serum as described (12).

Nucleic acids. Methods for preparing nucleic acids, electrophoresis of DNA and RNA in agarose gels, transfer to nitrocellulose, hybridization of nitrocellulose filters to DNA probes, and washing of filters were all as described (43). ${ }^{32} \mathrm{P}$ labeling of DNA probes by nick translation of DNA fragments previously purified on agarose and acrylamide gels was as described (43). The GRP probe used in gel blotting experiments is a 0.9-kb near full length cDNA fragment (13). The arginine vasopressin (AVP) probe is a 345-bp Sau 3A-Rsa I genomic fragment encoding the first exon and $5^{\prime}$ flanking sequences of the human prepro AVP-NPII gene (44). The beta actin probe is a $2.0-\mathrm{kb}$ cDNA fragment encompassing most of the human beta actin mRNA (45).

Nuclear run on assay. Nuclei were isolated from $2 \times 10^{7}$ cells by Dounce homogenization ( 10 strokes with a " $B$ " pestle) in $10 \mathrm{mM}$ Tris pH 7.4, $3 \mathrm{mM} \mathrm{CaCl}_{2}, 2 \mathrm{mM} \mathrm{MgCl}$, collected by centrifugation, resuspended in nuclear freezing buffer as described (46), and frozen in aliquots at $-70^{\circ} \mathrm{C}$. Run-on transcription was performed as described (46), including base hydrolysis of RNA into 100-200 nucleotide fragments, approximately the length of the RNA extensions synthesized in vitro. ${ }^{32}$ P-labeled RNA $\left(5-15 \times 10^{6} \mathrm{cpm}\right)$ was hybridized to $1-2.5 \mu \mathrm{g}$ single-stranded M13 DNA containing no insert (negative control), beta actin insert (positive control), or full length human GRP cDNA fragment in an antisense orientation (sense target) or a sense orientation (anti-sense transcription target). Comparison of these filter-immobilized targets allows determination of the amount of primary transcription from the GRP locus relative to the beta actin reference, as well as the polarity of transcription (sense or anti-sense). Autoradiography was performed using Kodak XAR film and Cronex "Quanta 3" screens (DuPont Instruments, Wilmington, DE) with varying exposure times (2-7 d). Scanning densitometer analysis was performed on a (GS 300; Hoefer Scientific Instruments, San Francisco, CA) scanning densitometer. The levels measured were determined by integrating the densitometric peaks for sense GRP transcription, and normalizing the area under the curve relative to that determined for beta actin transcription.

Primer extension. A 21-bp oligonucleotide complementary to sequence in GRP cDNA was synthesized on an Applied Biosystems (Foster City, CA) model 380B DNA synthesizer. The synthetic oligonucleotide was end labeled using T4 polynucleotide kinase and [ $\left.{ }^{32} \mathrm{P}\right] \mathrm{ATP}$ (43). $5 \mathrm{ng}$ of oligonucleotide primer and $5 \mu \mathrm{g}$ of polyadenylated mRNA in $10 \mu$ l of $0.4 \mathrm{M} \mathrm{NaCl}, 10 \mathrm{mM}$ piperazine- $N, N^{\prime}$-bis(2-ethanesulfonic acid) $\mathrm{pH} 6.4$, were sealed in a glass capillary, heated to $85^{\circ} \mathrm{C}$ for $4 \mathrm{~min}$, and annealed overnight at $58^{\circ} \mathrm{C}$. The sample was then added to an $80 \mu \mathrm{l} \mathrm{mix}$ of $25 \mathrm{U}$ AMV reverse transcriptase, $10 \mathrm{mM}$ DTT, $6 \mathrm{mM} \mathrm{MgCl} 2,50 \mathrm{mM}$ Tris, $\mathrm{pH} 8.2,0.5 \mathrm{mM}$ in each of dATP, dCTP, dGTP, and dTTP, and incubated at $42^{\circ} \mathrm{C}$ for $1 \mathrm{~h}$. The reaction was terminated by addition of $2.5 \mu \mathrm{l}$ of $0.5 \mathrm{M}$ EDTA followed by extraction with phenol-chloroform and then ethanol precipitation. The primer extended species was sized by electrophoresis on a $5 \%$ polyacrylamide $8 \mathrm{M}$ urea gel as described (43).

S1 nuclease protection assay. A GRP genomic clone in M13 was primer extended to prepare a single stranded ${ }^{32} \mathrm{P}$ mass-labeled probe (43). The M13 clone was primed with the same oligonucleotide used for the primer extension analyses of GRP mRNA. The S1 probe and oligonucleotide were therefore coterminal at their respective $5^{\prime}$ ends. Protection of labeled probe from $\mathrm{S} 1$ nuclease was assayed essentially as described (43). Briefly, the probe was added to $2 \mu \mathrm{g}$ of polyadenylated RNA and annealed in $50 \mu \mathrm{l}$ of $0.4 \mathrm{M} \mathrm{NaCl}, 0.02 \mathrm{M}$ Tris, $\mathrm{pH} 7.5,0.002$ M EDTA, 70\% formamide overnight at $54^{\circ} \mathrm{C}$. Hybridization reactions were diluted to $400 \mu$ l, adjusted to $0.3 \mathrm{M} \mathrm{NaCl}, 0.03 \mathrm{M} \mathrm{Na}$ acetate, $\mathrm{pH}$ 4.5, and $0.003 \mathrm{M} \mathrm{ZnSO}_{4} .100 \mathrm{U}$ of $\mathrm{S} 1$ nuclease (Boehringer Mannheim, Chemicals, Indianapolis, IN) were added, and digestion was allowed to proceed at $37^{\circ} \mathrm{C}$ for $2 \mathrm{~h}$. The reaction was terminated by extraction with phenol-chloroform followed by ethanol precipitation.
The protected species was resolved by electrophoresis on a $5 \%$ polyacrylamide $8 \mathrm{M}$ urea gel.

Methylation analysis. DNA from individual cell lines was digested with Bam HI. After organic extraction and ethanol precipitation, a 10- $\mu \mathrm{g}$ aliquot was further digested with $35 \mathrm{U}$ of either Hpa II or Msp I at $37^{\circ} \mathrm{C}$ for $3 \mathrm{~h}$. Digests were subjected to electrophoresis on agarose gels, transferred to nitrocellulose and hybridized with DNA probes as above. As mitochondrial DNA is not methylated at CpG dinucleotides (Battey, J., unpublished results), completeness of restriction enzyme digestions was established by hybridizing the filters with a mitochondrial probe.

DNase I hypersensitivity assay. Nuclei were prepared by lysis of cells with NP-40 as described (47). Aliquots of $3 \times 10^{7}$ nuclei were digested for 15 min with increasing unit amounts of DNase I starting at 0 and increasing twofold from $0.235,0.47,0.94,1.87,3.74$, stepwise to 60 , and the DNA was then extracted immediately after digestion as described (47). DNA was quantitated by absorbance at $260 \mathrm{~nm} .11 \mu \mathrm{g}$ of DNA from each digest were digested with Bam HI, size fractionated by agarose gel electrophoresis, stained with ethidium bromide, and transferred to nitrocellulose. The positions of DNase I hypersensitive sites were located by the indirect end labeling method (40).

DNA sequence determination. Nucleotide sequences of GRP clones in $\mathrm{M} 13$ vectors were determined using a modification of the dideoxynucleotide chain termination technique (43).

\section{Results}

The level of primary transcription correlates with the level of steady-state prepro GRP $m R N A$. Four SCLC cell lines that express differing levels of prepro GRP mRNA were compared. Fig. $1 A$ shows an RNA blot comparison of total RNA isolated from the four lines. After hybridization with a GRP probe, the highest levels of the $0.9 \mathrm{~kb}$ GRP mRNA are found in H510, with lower but readily detectable levels also seen in H209. In contrast, no detectable GRP mRNA is seen in either N417 or H82, even on longer autoradiographic exposures (not shown). The same blot was subsequently hybridized with a beta actin reference gene probe, establishing that equivalent levels of steady-state beta actin mRNA are found in all four cell lines.

We were interested to see if the differing levels of steadystate GRP mRNA observed in these four cell lines resulted from corresponding differences in primary transcription. To compare the relative amounts of primary prepro GRP gene transcription, we used a nuclear run-on transcription assay. In this assay, RNA polymerase II extends previously initiated primary transcripts from isolated nuclei in the presence of [ ${ }^{32}$ P]UTP. The amount of incorporated label measures the density of nascent mRNA chains along the gene at the time of nuclear isolation. Gene-specific incorporated counts are compared by hybridization to strand-specific cloned DNA from the gene of interest, immobilized on a nitrocellulose filter. Thus, the relative polymerase density and polarity of transcription along a number of genes can be determined. If GRP gene regulation is primarily determined at the level of transcription, cell lines with the highest levels of steady-state mRNA should show the highest levels GRP specific transcription during the run-on assay. Fig. $1 B$ shows the results of a typical nuclear run-on experiment comparing GRP-specific counts incorporated in the four SCLC cell lines studied. H510 shows the highest level of in vitro-labeled transcripts hybridizing to a GRP cDNA "sense" target, with H209 showing lower but detectable levels. Densitometric analysis of steady-state mRNA levels in Fig. $1 A$ shows that $\mathrm{H} 510$ has 2.0 times as 
A

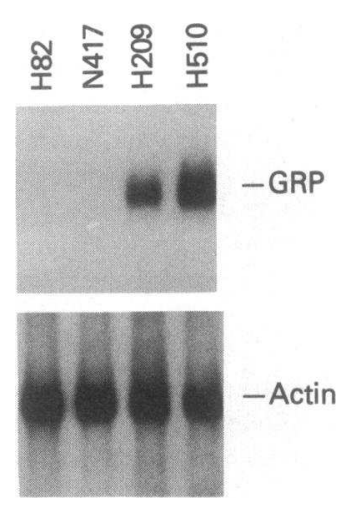

B

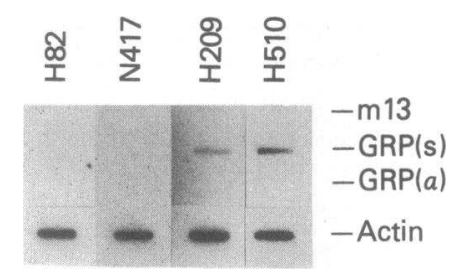

Figure 1. Steady-state and nuclear run-on transcription analysis of GRP mRNA. (A) Northern blot analysis comparing the steadystate levels of prepro GRP mRNA in four human SCLC cell lines. After gel fractionation and transfer, equal amounts of total RNA from four SCLC cell lines is hybridized to a GRP probe. The same blot is subsequently hybridized to a human beta actin probe, demonstrating that equivalent amounts of intact RNA were present in all four samples. $(B) \mathrm{Nu}-$ clear run-on comparison of GRP primary transcription in four SCLC cell lines. After in vitro labeling of nascent transcripts in iso-

lated nuclei, the purified RNA is hybridized to specific gene targets bound to nitrocellulose filters. Comparison of the ${ }^{32} \mathrm{P}$-labeled counts hybridized to each target reflects the level of primary transcription of the target locus. The run on analysis is normalized using a beta actin reference target. Note that detectable GRP transcription is observed only in lines that express detectable steady-state levels of GRP mRNA, and that the level of primary transcription reflects the level of steady-state mRNA as illustrated in $A$. The specificity of the assay is indicated by the absence of hybridizing counts to the $\mathrm{m} 13$ vector target. All detectable transcription is in a sense orientation ( $\left(5^{\prime}\right.$ to $3^{\prime}$ through the gene) as determined by comparing the sense (s) and antisense (a) targets.

much mRNA as H209. A comparable analysis of the primary transcription by nuclear run-on analysis (Fig. $1 B$ ) shows that H510 has a 2.0 -fold greater primary transcription level than H209 (H510; GRP 24\% of beta actin; H209, GRP $11.4 \%$ of beta actin). Both $\mathrm{H} 82$ and $\mathrm{N} 417$ show no detectable sense GRP transcription, even though both cell lines show beta actin run-on signals and steady-state mRNA levels comparable to those observed for $\mathrm{H} 209$ and $\mathrm{H} 510$. Identical results were observed in several independent nuclear run-on experiments examining expressing and nonexpressing SCLC cell lines. The level of steady-state GRP mRNA directly correlates with the level of run-on transcription and therefore is determined in a large part by differences in primary transcriptional activity.

The GRP gene is not amplified or rearranged in cell lines expressing the gene. Southern blot analysis of equivalent amounts of Hind III digested genomic DNA from two human SCLC cell lines that express the GRP gene (H209, H510) and from normal human leukocytes is shown in Fig. 2. The GRP probe detects the three exons of the gene on $11 \mathrm{~kb}$ (exon 1), 4.6 $\mathrm{kb}$ (exon 2), and $2.9 \mathrm{~kb}$ (exon 3) genomic fragments (13). The filter was then hybridized to an AVP probe, which detects a 2.2-kb Hind III genomic fragment of the human prepro AVP neurophysin II gene. This gene is neither expressed nor amplified in any of the four cell lines examined here, and therefore

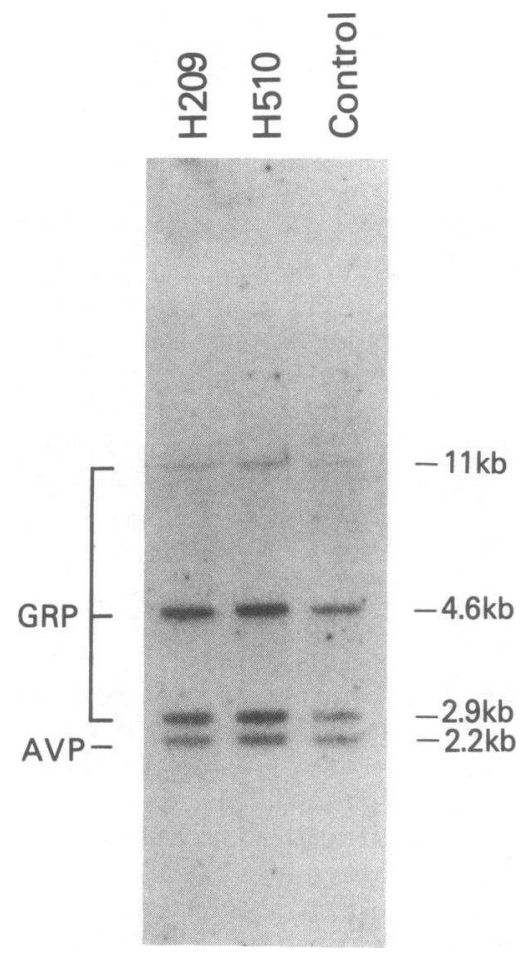

Figure 2. Genomic blot analysis of the GRP gene in the two SCLC cell lines expressing mRNA. Equal amounts of Hind III digested genomic DNA from H209, H510, and normal human leukocyte DNA was resolved by electrophoresis, blotted and hybridized to both a GRP probe and a human AVP probe. The GRP probe hybridizes to an $11 \mathrm{~kb}$ exon 1 encoding fragment (weakly), a 4.6-kb exon two encoding fragment and a 2.9-kb exon three fragment. The AVP probe hybridizes to a 2.2-kb exon 1 fragment, and serves as a single copy gene reference that is not amplified or expressed in the cell lines examined. Note that

the 2.2-kb AVP and 2.9-kb GRP bands are of roughly equivalent intensity within a given DNA sample, ruling out amplification of the GRP gene. No rearrangement of any of the three exon-encoding Hind III fragments is seen in either of the two expressing cell lines (H209 and H510).

represents a reasonable single copy gene reference. No significant amplification or rearrangement of the GRP gene is evident in this experiment. In addition, no evidence for GRP gene rearrangement or amplification was observed in any SCLC DNA examined to date, including the nonexpressing cell lines $\mathrm{H} 82$ and $\mathrm{H} 417$ (data not shown).

Identification of a unique site of initiation of GRP $M R N A$ transcription in SCLC. Fig. 3 shows the transcription initiation site for GRP mRNA located by two independent methods, S1 nuclease protection and primer extension, at a position $155 \mathrm{bp}$ $5^{\prime}$ of the first Sma I restriction site in exon 1 of the GRP gene. The S1 probe and oligonucleotide primer both begin at the same Sma I site in GRP mRNA. As would be predicted, both methods produce fragments of equal size, extending $155 \mathrm{bp}$ from the Sma I site to the mRNA initiation site (Fig. 3, schematic and autoradiogram). The same initiation site is found in two different SCLC cell lines, $\mathrm{H} 209$ and H510, both of which express the GRP gene (Fig. 1). H929, a human myeloma cell line that does not express GRP (northern analysis not shown), serves as a negative control in both experiments. Several additional faint bands at 295, 220, and $130 \mathrm{bp}$ are also seen in the $\mathrm{S} 1$ protection analysis. It is unlikely that these species represent minor GRP initiation sites since no corresponding size bands are seen in the primer extension analysis even on long exposures of the autoradiogram. Also seen is the nonspecific remainder of a small amount of full length probe, present in all S1 digests, including those containing probe without any added RNA (Fig. 3, - lane). This is characteristic of the technique (43). Faint bands of 280 and 400 bp are seen in the 

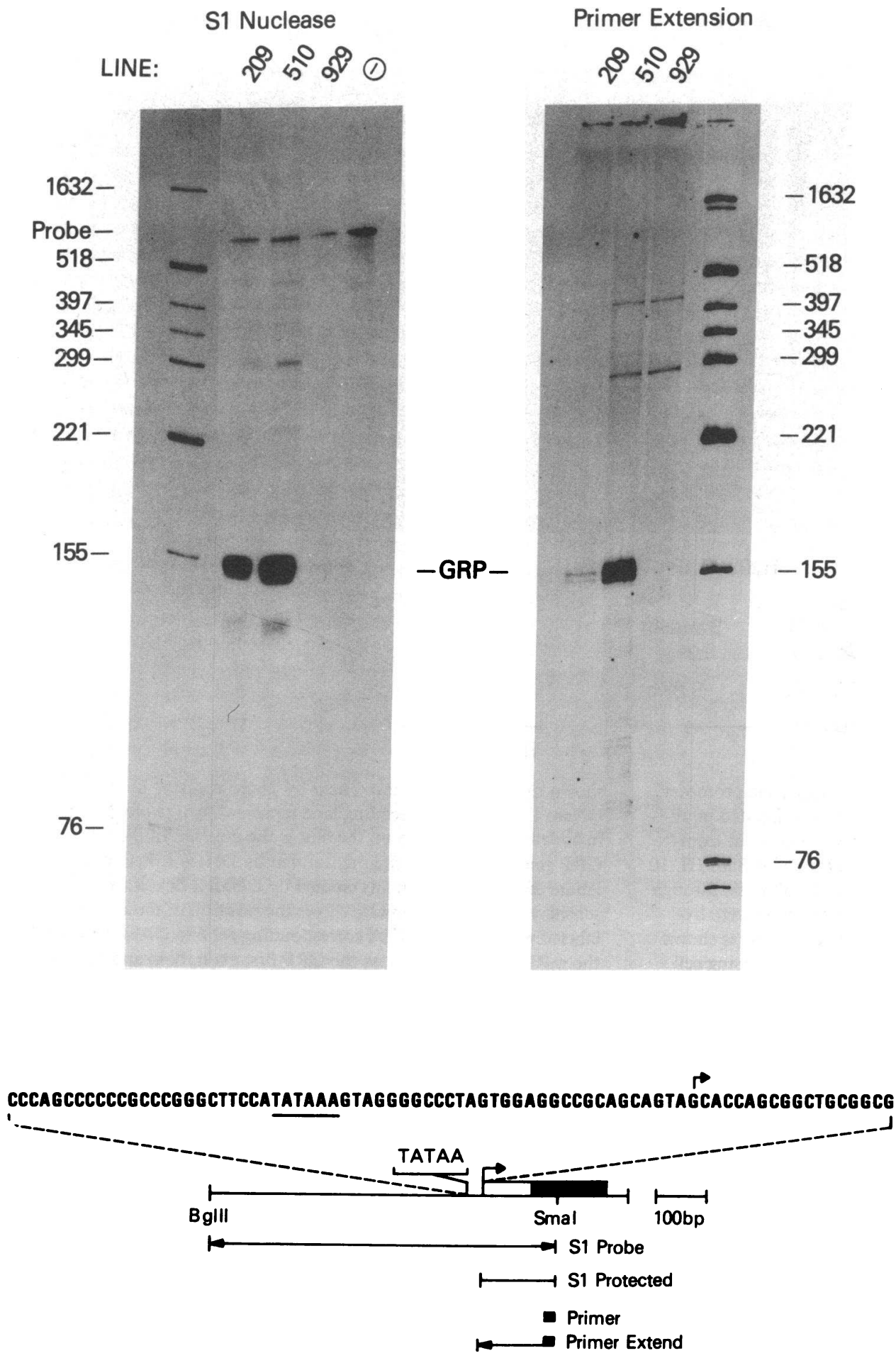

Figure 3. Identification of the site of initiation of transcription of GRP mRNA in SCLC. Primer extension: a 21 bp ${ }^{32} \mathrm{P}$-labeled oligonucleotide probe complementary to GRP cDNA sequence was annealed to 5 $\mu \mathrm{g}$ of polyadenylated RNA from each of three cell lines. Reverse transcriptase elongated the primer to reach the $5^{\prime}$ end of the RNA template. The reaction products were resolved on an 8-M urea 5\% polyacrylamide gel and visualized by autoradiography on XAR-5 film. The band labeled GRP, specific to GRP expressing lines $\mathrm{H} 209$ and $\mathrm{H} 510$, identifies the GRP mRNA start site. Size markers are shown at right. H929 does not express the GRP gene. The schematic shows the GRP genomic structure around the promoter. The first exon is boxed, the open portion being noncoding, the darkened portion coding sequence. The position of the primer and the primer extended species are shown. The genomic sequence near the mRNA start site is shown above the schematic. The mRNA start site is designated with an arrow and the TATAA box is underlined. S1 nuclease protection: a ${ }^{32} \mathbf{P}$ mass labeled single strand DNA probe was constructed coterminal at its $5^{\prime}$ end with the above primer extension oligonucleotide and complementary in sequence to the GRP genomic DNA sense strand. The probe was annealed to $2 \mu \mathrm{g}$ of polyadenylated RNA from each of three cell lines. Portions of the probe not protected by annealed RNA were digested with $\mathrm{S} 1$ nuclease. The protected species were determined as above. The band labeled GRP identifies the GRP mRNA start site in GRP expressing lines. The - lane shows S1 digestion of probe with no RNA present. The schematic shows the position of the $S 1$ probe and the protected species. primer extension assay. These species are not a result of primer extension after oligonucleotide priming of GRP mRNA as they are present equally in both GRP-producing and nonproducing cell lines. The nucleotide sequence surrounding the GRP mRNA initiation site is shown in Fig. 3. A TATAA sequence fitting the consensus Goldberg-Hogness box is found $31 \mathrm{bp} 5^{\prime}$ of the mRNA start site identified in this experiment, consistent with initiation of transcription by RNA polymerase II at this location (48).
No specific pattern of DNA methylation near the GRP promoter correlates with gene expression. DNAs were prepared from the four SCLC cell lines and analyzed for methylation at several potential CCGG methylation sites near the GRP promoter. A methylated site is detected as a site resistant to digestion with Hpa II but sensitive to the Msp I enzyme isoschizomers. The sites examined are 46, 113, 130, 242, 300, 366, and $\sim 1,200$ bp $5^{\prime}$ to the unique initiation site. Methylation was sometimes observed at selected sites, but expression of the 

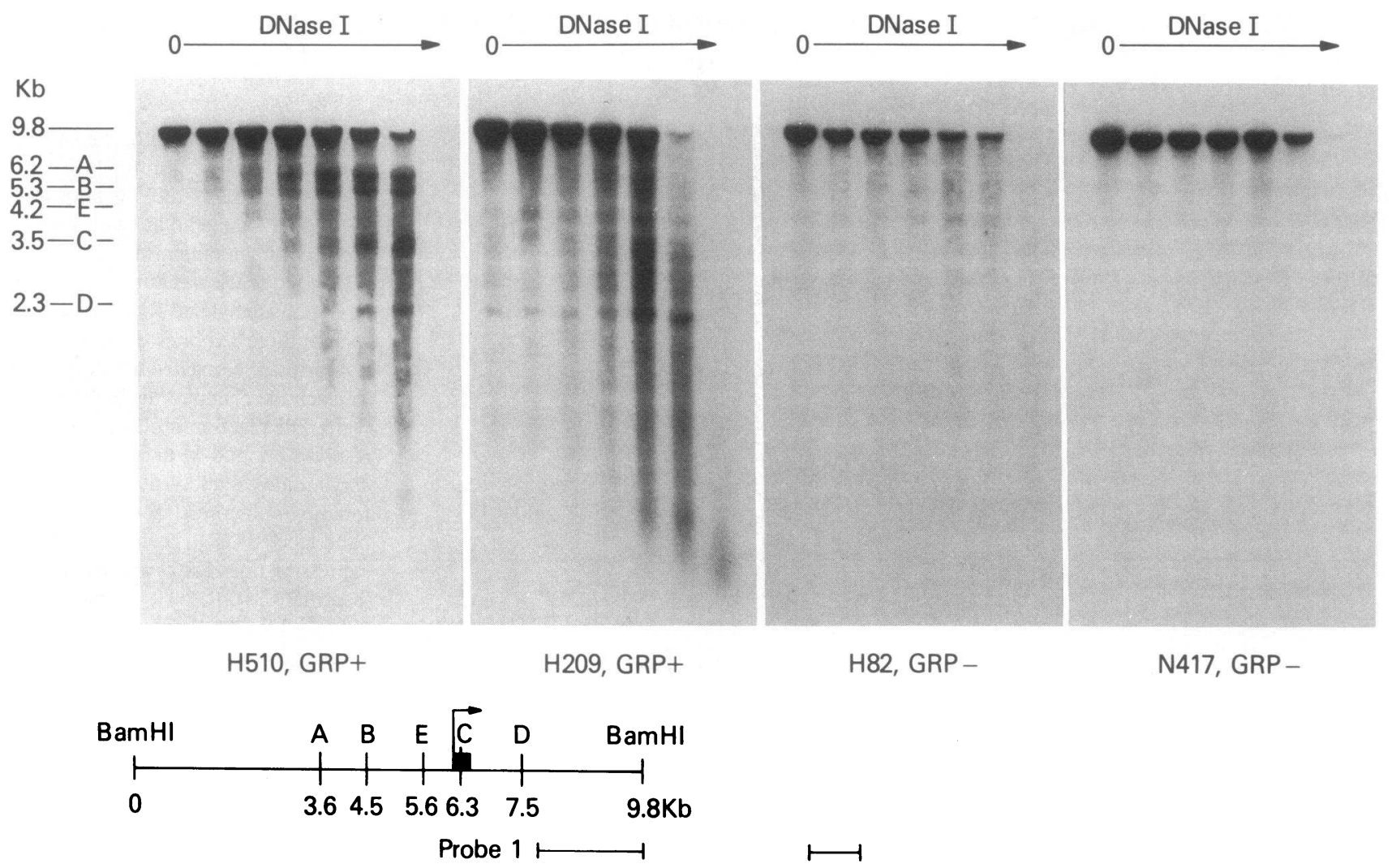

Figure 4. DNase I hypersensitive sites near the GRP gene promoter. Nuclei from each cell line shown were prepared and digested in aliquots with increasing levels of DNase I. DNA was extracted from each digest and then further digested to completion with Bam HI. 10 $\mu \mathrm{g}$ of DNA from each digest was resolved by electrophoresis through $0.8 \%$ agarose and transferred to nitrocellulose. The blots were hybridized with the ${ }^{32} \mathrm{P}$-labeled GRP probe 1 whose position is shown in the schematic. Shown are results from two GRP expressing cell lines H510 and H209, and from two GRP nonexpressing cell lines, H82 and N417. In each panel nuclei not exposed to DNase I are

GRP gene did not correlate with any apparent pattern of methylation seen in the blots (data not shown).

Specific DNase I hypersensitive sites are present near the GRP promoter only in cell lines that express the GRP gene. Hybridization with the GRP probe No. 1 demonstrates a 9.8$\mathrm{kb}$ promoter region fragment present in all four SCLC cell lines before DNase I treatment (Fig. 4, O DNase lanes), corresponding to the predicted germ line $9.8 \mathrm{~kb}$ Bam HI fragment (Fig. 4, schematic). In nuclei from GRP expressing SCLC lines $\mathrm{H} 510$ and H209, increasing the dose of DNase I introduces cuts in the 9.8-kb parent Bam HI region at four sites resulting in the appearance of the smaller daughter bands $A-D$. In contrast, none of the hypersensitive sites $A-D$ are found in SCLC lines $\mathrm{H} 82$ and N417, which do not express GRP (Fig. 4). Even prolonged exposure of the blots fails to reveal evidence of hypersensitive sites $A-D$ in the nonexpressing cell lines (data not shown). An additional hypersensitive site labeled $\mathrm{E}$ is also detected in H209, and weakly seen in H510 (GRP-expressing) and H82 (GRP nonexpressing). Two minor DNase I hypersensitive sites located between sites $C$ and $D$ are faintly seen in $\mathrm{H} 510$ and $\mathrm{H} 209$. As these sites are less intense than the major sites, they will not be further discussed.



shown in the 0 lane, followed next by nuclei digested by $0.235 \mathrm{U}$ DNase I, with each succeeding lane representing a twofold increase in added DNase. Shown on the blot is the position of the 9.8-kb GRP genomic Bam HI fragment uncut by DNase I. Letters $A-E$ designate the smaller fragments created by DNase I digestion at hypersensitive sites. The schematic shows the position of these sites, each labeled with the letter of its corresponding gel band. Also shown is the mRNA start site, arrow; the GRP first exon, box; and the position of the Bam HI restriction sites.

DNase I hypersensitive sites actually represent DNase I hypersensitive regions of 50 to 400 bp length (30). Probe 1, employed in Fig. 4, is $3^{\prime}$ of hypersensitive sites $A-D$ and maps the $3^{\prime}$ boundary of each of these regions. In an otherwise identical experiment, GRP probe 2, which is $5^{\prime}$ of the hypersensitive sites, maps the $5^{\prime}$ boundary of the hypersensitive hypersensitive sites present in the GRP producer $\mathrm{H} 510$ and absent in the GRP nonproducer N417 (Fig. 5). Specifically, probe 2 resolves the $5^{\prime}$ most site, $\mathrm{A}$, into two sites, $\mathrm{A}_{1}{ }_{1}$ and $\mathrm{A}_{2}{ }_{2}$, and establishes $5^{\prime}$ boundaries $B^{*}$ and $C^{*}$ for sites $B$ and C. Probe 2 does not resolve site $\mathrm{D}$. The predicted band $\mathrm{D}^{*}$ would fall just beneath the parent 9.8-kb Bam HI fragment where the background is highest, perhaps explaining the failure to detect this band.

\section{Discussion}

GRP has been proposed to act as an autocrine growth factor in a subset of SCLC cell lines (17). The autocrine growth loop created could reflect a disorder in regulation of expression of the GRP gene or the GRP receptor gene, or could reflect an abnormality in transduction of the signal sent by the GRP 

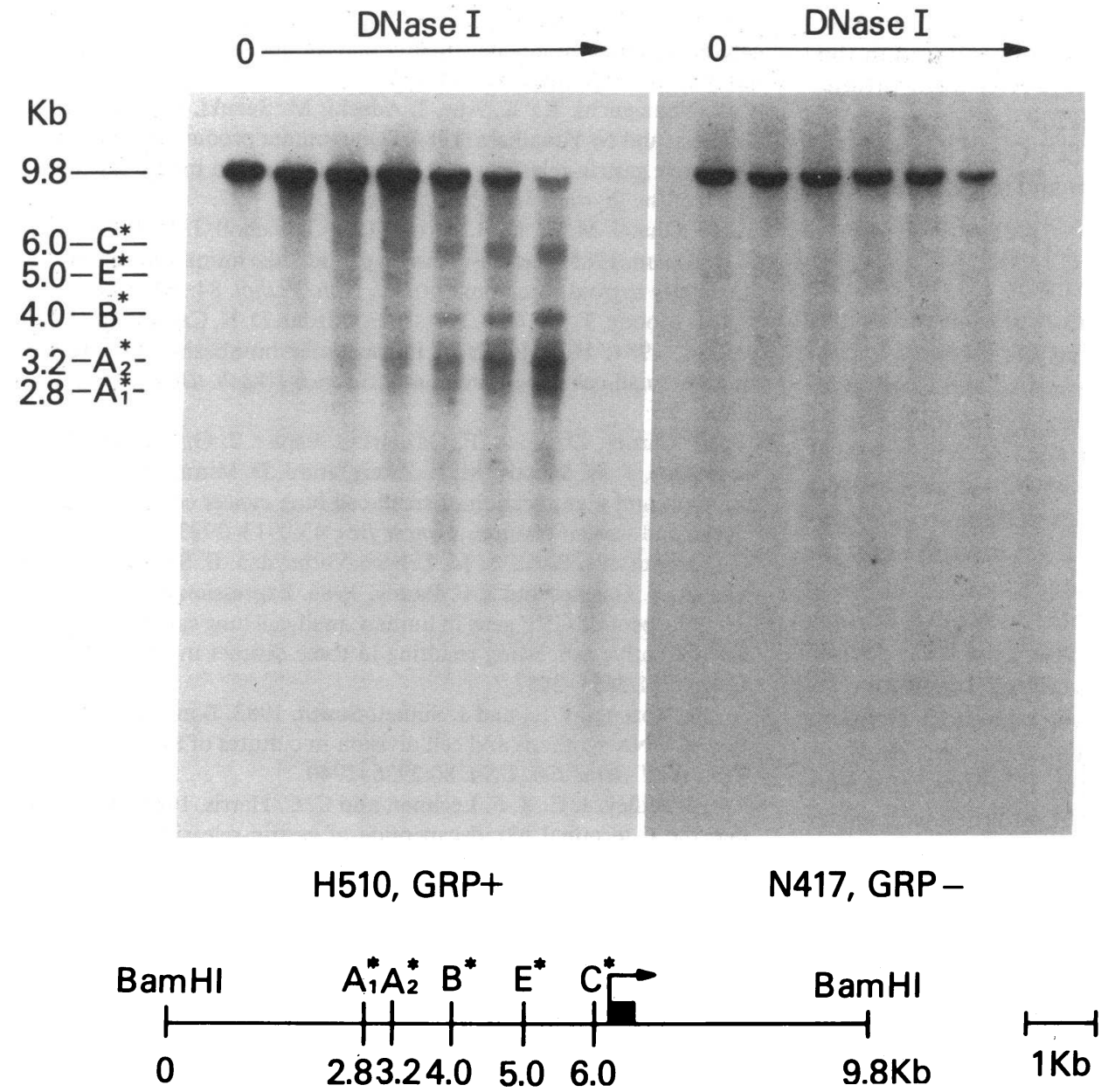

Probe $2 \longmapsto$

receptor. This study begins a dissection of this pathologic state by examining those structural features of the GRP gene that may be involved in regulating GRP gene expression. We established that the level of primary transcription appears to be important in determining the level of steady state mRNA. Therefore, we focused attention on the promoter region of the gene.

We show by two independent techniques, S1 nuclease protection and primer extension, a single initiation site of GRP mRNA transcription. By different processes both techniques produce a DNA strand complementary to the GRP mRNA from the $5^{\prime}$ cap site to a $3^{\prime}$ Sma I site. Primer extension alone could give a misleading result if elongation by reverse transcriptase were blocked $3^{\prime}$ of the cap site by secondary structure in the mRNA. S1 nuclease protection alone could give a misleading result if the tumor encoded sequence in the mRNA differed from the placental sequence in the $\mathrm{S} 1$ probe, or if the probe contained an unsuspected intron. Both cases would produce regions where the $\mathrm{S} 1$ probe and mRNA were not complementary and where S1 nuclease could cleave. These possibilities for error are rendered unlikely by the identity of the S1 nuclease and primer extension results. A previously published analysis of others using S1 nuclease protection also locates the principal site of mRNA initiation within $7 \mathrm{bp}$ of the position found in this study and also reports a second minor site of mRNA initiation located $12 \mathrm{bp} 5^{\prime}$ of the major site (20). II initiation site (48).
Figure 5. 5' boundaries of DNase I hypersensitive sites. Blots identical to those shown in Fig. 4 were hybridized with the ${ }^{32} \mathrm{P}$-labeled GRP probe 2 shown in the schematic. Sites $A^{*}-E^{*}$ on the schematic correspond to the $5^{\prime}$ boundaries of sites A-E, whose $3^{\prime}$ boundaries detected with probe 1 are shown in Fig. 4. Fragments $A^{*}-E^{*}$ are produced by DNase I cleavage at sites $A^{*}-E^{*}$, respectively. All other designations are the same as in Fig. 4.

The GRP initiation site we find in the SCLC cell is appropriately positioned 31 bp downstream from a TATAA box and adjacent GC-rich region, consistent with an RNA polymerase

The structural feature best correlating with GRP expression is the presence of several DNase I hypersensitive sites (A-D) near the GRP mRNA start site, which we find only in SCLC cell lines that express the GRP gene. DNase I hypersensitive sites are sites in chromatin that, by a process poorly understood, have acquired a structure different from bulk chromatin (30). For a large number of genes that have been examined, specific hypersensitive sites have been defined and shown to be necessary but not sufficient for gene expression (30). The appearance of some hypersensitive sites is developmentally regulated; the appearance of others is hormonally regulated $(30,35-38)$. Some sites whose presence is thought to be permissive for expression of globin family genes can be transmitted from parent to daughter cells over many generations, even in the absence of globin gene expression (49). A few DNase I hypersensitive sites have been shown to contain specific cis acting regulatory sequences recognized by purified trans-acting factors $(21,30,39-42)$. The actual protein factors needed to establish a DNase I hypersensitive site, though, have yet to be determined. Recently a DNase I hypersensitive site has been associated with a negative regulatory element, one involved in control of transcription of the $c-m y c$ gene (50). It 
would therefore be premature to suggest at this time the precise function of the four DNase I hypersensitive sites found in the 5 ' portion of the GRP gene. Site E is observed most prominently in the GRP expressing cell line $\mathrm{H} 209$, less prominently in H510, but also in the nonexpressing SCLC cell line H82. A direct relationship between transcription and site $\mathrm{E}$ is less convincing than for the other sites A-D.

Close examination reveals the DNase I hypersensitive sites can be regions several hundred base pairs in length, each of which may therefore be involved in binding of multiple regulatory factors. Indeed our data suggest that the DNase I hypersensitive region associated with expression of the GRP gene may include a significant portion of the several kilobases of DNA flanking the GRP message start site. Recent technical advances make it possible to footprint within single DNase I hypersensitive sites the actual nucleotides making in vivo contact with protein regulatory factors (51). An in vitro assay for proteins that bind defined DNA regulatory sequences has been described and used to partially purify some such DNA binding proteins (52-56). Finally functional assays have been devised in which reporter genes fused to cis acting regulatory sequences test the function of the putative regulatory elements (57). The DNase I hypersensitive sites defined in this study are candidates for such further investigations. It is hoped that such investigations will provide further insight into the mechanisms that govern the expression of the GRP gene.

\section{Acknowledgments}

We thank Eliot Spindel for providing a GRP genomic clone, Adi Gazdar for establishing SCLC cell lines, and Joseph Fedorko for expert assistance in oligonucleotide preparation. We thank John Minna, Timothy Bender, and Craig Thompson for their critical review of the manuscript, and Gena Parris for her expert assistance in preparation of the manuscript. Anne-Marie Lebacq-Verheyden is a permanent research associate of the Fonds National de la Recherche Scientifique (Belgium) and is supported in part by a European Organization for Research on Treatment of Cancer Fellowship at the National Cancer Institute. The work was supported in part by a grant from the Mather Foundation.

\section{References}

1. McDonald, T. J., H. Jornvall, G. Nilsson, M. Vagne, M. Ghatei, S. R. Bloom, and V. Mutt. 1979. Characterization of a gastrin-releasing peptide from porcine non-antral gastric tissue. Biochem. Biophys. Res. Commun. 90:227-233.

2. Moody, T. W., and C. B. Pert. 1979. Bombesin-like peptides in rat brain: quantitation and biochemical characterization. Biochem. Biophys. Res. Commun. 90:7-14.

3. Roth, K. A., E. Weber, and J. D. Barchas. 1982. Distribution of gastrin releasing peptide-bombesin-like immunostaining in rat brain. Brain Res. 251:277-282.

4. Brown, M., R. Allen, J. Villareal, J. Rivier, and W. Vale. 1978. Bombesin-like activity: radio-immunologic assessment in biological tissues. Life Sci. 23:2721-2726.

5. Walsh, J. H., H. C. Wong, and G. J. Dockray. 1979. Bombesinlike peptides in mammals. Fed. Proc. Am. Soc. Exp. Biol. 38:23152319.

6. Wharton, J., J. M. Polak, S. R. Bloom, M. A. Ghatei, E. Solcia, M. R. Brown, and A. Pearse. 1978. Bombesin-like immunoreactivity in the lung. Nature (Lond.). 273:769-770.

7. Yang, K., T. Ulich, I. Taylor, L. Cheng, and K. J. Lewin. 1983. Pulmonary carcinoids. Immunohistochemical demonstration of brain-gut peptides. Cancer (Phila.). 52:819-823.

8. Tamai, S., T. Kameya, K. Yamaguchi, N. Yanai, K. Abe, N.
Yanaihara, H. Yamazaki, and K. Kageyama. 1983. Peripheral lung carcinoid tumor producing predominantly gastrin-releasing peptide (GRP). Cancer (Phila.). 52:273-281.

9. Yamaguchi, K., K. Abe, I. Adachi, M. Suzuki, S. Kimura, T. Kameya, and N. Yanaihara. 1984. Concomitant production of immunoreactive gastrin-releasing peptide and calcitonin in medullary carcinoma of the thyroid. Metab. Clin. Exp. 33:724-727.

10. Ghatei, M. A., D. R. Springall, C. G. Nicholl, J. M. Polak, and S. R. Bloom. 1985. Gastrin-releasing peptide-like immunoreactivity in medullary thyroid carcinoma. Am. J. Clin. Pathol. 84:581-586.

11. Moody, T. W., C. B. Pert, A. F. Gazdar, D. N. Carney, and J. D. Minna. 1981. High levels of intracellular bombesin characterize human small-cell lung carcinoma. Science (Wash. DC). 214:12461248.

12. Carney, D. N., A. F. Gazdar, G. Bepler, J. G. Guccion, P. J. Marangos, T. W. Moody, M. H. Zweig, and J. D. Minna. 1985. Establishment and identification of small-cell lung cancer cell lines having classic and variant features. Cancer Res. 45:2913-2923.

13. Sausville, E. A., A. M. Lebacq-Verheyden, E. Spindel, F. Cuttitta, A. F. Gazdar, and J. F. Battey. 1986. Expression of the gastrinreleasing peptide GRP gene in human small-cell lung cancer. Evidence for alternative processing resulting in three distinct mRNAs. J. Biol. Chem. 261:2451-2457.

14. Rozengurt, E., and J. Sinnett-Smith. 1983. Bombesin stimulation of DNA synthesis and cell division in cultures of Swiss 3T3 cells. Proc. Natl. Acad. Sci. USA. 80:2936-2940.

15. Willey, J. C., J. F. Lechner, and C. C. Harris. 1984. Bombesin and the C-terminal tetradecapeptide of gastrin-releasing peptide are growth factors for normal human bronchial epithelial cells. Exp. Cell Res. 153:245-248.

16. Weber, S., J. E. Zukerman, D. G. Bostwick, K. G. Bensch, B. I. Sikic, and T. A. Raffin. 1985. Gastrin-releasing peptide is a selective mitogen for small cell lung carcinoma in vitro. J. Clin. Invest. 75:306309.

17. Cuttita, F., D. N. Carney, J. Mulshine, T. W. Moody, J. Fedorko, A. Fischler, and J. D. Minna. 1985. Bombesin-like peptides can function as autocrine growth factors in human small cell lung cancer. Nature (Lond.). 316:823-826.

18. Carney, D., F. Cuttitta, T. W. Moody, and J. D. Minna. 1987. Selective stimulation of small cell lung cancer clonal growth by bombesin and Gastrin-releasing peptide. Cancer Res. 47:821-825.

19. Spindel, E. R., W. W. Chin, J. Price, L. H. Rees, G. M. Besser, and J. F. Habener. 1984. Cloning and characterization of cDNAs encoding human gastrin-releasing peptide. Proc. Natl. Acad. Sci. USA. 81:5699-5703.

20. Spindel, E. R., M. D. Zilberberg, and W. W. Chin. 1987. Analysis of the gene and multiple mesenger ribonucleic acids (mRNAs) encoding human Gaștrin-releasing peptide: alternate RNA splicing occurs in neural and endocrine tissue. Mol. Endocrinol. 1:224-232.

21. Dynan, W., and R. Tjian. 1985. Control of eukaryotic messenger RNA sythesis by sequence-specific DNA-binding proteins. Nature (Lond.). 316:774-778.

22. Carr, F. E., L. R. Need, and W. W. Chin. 1987. Isolation and characterization of the rat thyrotropin beta-subunit gene. Differential regulation of two transcriptional start sites by thyroid hormone. $J$. Biol. Chem. 262:981-987.

23. Benyajati, C., N. Spoerel, H. Haymerle, and M. Ashburner. 1983. The messenger RNA for alcohol dehydrogenase in drosophila melanogaster differs in its $5^{\prime}$ end in different developmental stages. Cell, 33:125-133.

24. Battey, J., C. Moulding, R. Taub, W. Murphy, T. Stewart, H. Potter, G. Lenoir, and P. Leder. 1983. The human c-myc oncogene: structural consequences of translocation into the IgH locus in Burkitt lymphoma. Cell. 34:779-787.

25. Schibler, U., O. Hagenbuchle, P. K. Wellauer, and A. C. Pittet. 1983. Two promoters of different strengths control the transcription of the mouse alpha-amylase gene Amy-la in the parotid gland and the liver. Cell. 33:501-508. 
26. Dalla Favera, R., F. Wong-Staal, and R. C. Gallo. 1982. Onc gene amplification in promyelocytic leukaemia cell line HL-60 and primary leukaemic cells of the same patient. Nature (Lond.). 299:6163.

27. Little, C., M. Nau, D. Carney, A. Gazdar, and J. D. Minna. 1983. Amplification and expression of the c-myc oncogene in human lung cancer cell lines. Nature (Lond.). 306:194-196.

28. Nau, M., B. Brooks, J. Battey, E. Sausville, A. Gazdar, I. Kirsch, O. W. McBride, V. Bertness, G. Hollis, and J. D. Minna. 1985. L-myc, a new myc-related gene amplified and expressed in human small-cell lung cancer. Nature (Lond.). 318:69-73.

29. Nau, M., B. Brooks, D. Carney, A. Gazdar, J. Battey, E. Sausville, and J. D. Minna. 1986. Human small-cell lung cancers show amplification and expression the N-myc gene. Proc. Natl. Acad. Sci. USA. 83:1092-1096.

30. Eissenberg, J., I. Cartwright, G. Thomas, and S. Elgin. 1985. Selected topics in chromatin structure. Annu. Rev. Genet. 19:485-536.

31. Doerfler, W. 1983. DNA methylation and gene activity. Annu. Rev. Biochem. 52:93-124.

32. Razin, A., and A. Riggs. 1980. DNA methylation and gene function. Science (Wash. DC). 210:604-610.

33. Karlsson, S., and A. W. Nienhuis. 1985. Developmental regulation of human globin genes. Annu. Rev. Biochem. 54:1071-1108.

34. Busslinger, M., J. Hurst, and R. A. Flavell. 1983. DNA methylation and the regulation of globin gene expression. Cell. 34:197-206.

35. Weintraub, H., A. Larsen, and M. Groudine. 1981. Alpha-globin-gene switching during the development of chicken embryos: expression and chromosome structure. Cell. 24:333-344.

36. McGhee, J., W. Wood, M. Dolan, J. Engel, and G. Felsenfeld. 1981. A 200 base pair region at the $5^{\prime}$ end of the chicken adult betaglobin gene is accessible to nulease digestion. Cell. 27:44-55.

37. Benvenisty, N., and L. Reshef. 1987. Developmental acquisition of DNase I sensitivity of the phosphoenolpyruvate carboxykinase (GTP) gene in rat liver. Proc. Natl. Acad. Sci. USA. 84:1132-1136.

38. Burch, J., and H. Weintraub. 1983. Temporal order of chromatin structural changes associated with activation of the major chicken vitellogenin gene. Cell. 33:65-76.

39. Jongstra, J., T. Reudelhuber, P. Oudet, C. Benoist, C. Chae, J. Jeltsch, D. Mathis, and P. Chambon. 1984. Induction of altered chromatin structures by simian virus 40 enhancer and promoter elements. Nature (Lond.). 307:708-714.

40. Wu, C. 1980. The $5^{\prime}$ ends of Drosophila heat shock genes in chromatin are hypersensitive to DNase I. Nature (Lond.). 286:854860 .

41. Wu, C. 1984. Two protein-binding sites in chromatin implicated in the activation of heat-shock genes. Nature (Lond.). 309:229 234.

42. Wu, C. 1984. Activating protein factor binds in vitro to up stream control sequences in heat shock gene chromatin. Nature (Lond.). 311:81-84.

43. Davis, L. G., M. D. Dibner, J. F. Battey. 1986. Basic Methods in Molecular Biology. Elsevier Science Publishing Co., Inc., New York. $388 \mathrm{pp}$.

44. Sausville, E., D. Carney, and J. Battey. 1985. The human vasopressin gene is linked to the oxytocin gene and is selectively expressed in a cultured lung cancer cell line. J. Biol. Chem. 260:10236-10241.

45. Ponte, P., S. Y. Ng, J. Engel, P. Gunning, and L. Kedes. 1984. Evolutionary conservation in the untranslated regions of actin mRNAs: DNA sequence of a human beta-actin cDNA. Nucl. Acids Res. 12:1687-1696.

46. Groudine, M., M. Peretz, H. Weintraub. 1981. Transcriptional regulation of hemoglobin switching in chicken embryos. Mol. Cell. Biol. 1:281-288.

47. Siebenlist, U., L. Hennighausen, J. Battey, and P. Leder. 1984. Chromatin structure and protein binding in the putative regulatory region of the c-myc gene in Burkitt lymphoma. Cell. 37:381-391.

48. Lewin, B. 1983. Genes. John Wiley and Sons, Inc., New York. 186.

49. Groudine, M., and H. Weintraub. 1982. Propagation of globin DNAase I-hypersensitive sites in absence of factors required for induction: a possible mechanism for determination. Cell. 30:131-139.

50. Bentley, D., and M. Groudine. 1986. A block to elongation is largely responsible for decreased transcription of c-myc in differentiated HL60 cells. Nature (Lond.). 321:702-706.

51. Jackson, P. D., and G. Felsenfeld. 1985. A method for mapping intranuclear protein-DNA interactions and its application to a nuclease hypersensitive site. Proc. Natl. Acad. Sci. USA. 82:2296-2300.

52. Carthew, R., L. Chodosh, and P. Sharp. 1985. An RNA polymerase transcription factor binds to an upstream element in the adenovirus major late promoter. Cell. 43:439-448.

53. Singh, H., R. Sen, D. Baltimore, and P. Sharp. 1986. A nuclear factor that binds to a conserved sequence motif in transcriptional control elements of immunoglobulin genes. Nature (Lond.). 319:154158.

54. Briggs, M., J. Kadonaga, S. Bell, and R. Tjian. 1986. Purification and biochemical characterization of the promoter-specific transcription factor, Spl. Science (Wash. DC). 234:47-52.

55. Lenardo, M., J. Pierce, and D. Baltimore. 1987. Proteịn-binding sites in Ig gene enhancers determine transcriptional activity and inducibility. Science (Wash. DC). 236:1573-1577.

56. Wu, C., S. Wilson, B. Walker, I. Dawid, T. Paisley, V. Zimarino, and H. Veda. 1987. Purification and properties of Drosophila heat shock activator protein. Science (Wash. DC). 238:1247-1253.

57. Gorman, C., L. Moffat, and B. Howard. 1982. Recombinant genomes which express chloramphenicol acetyltransferase in mammalian cells. Mol. Cell. Biol. 2:1044-1051. 